ic

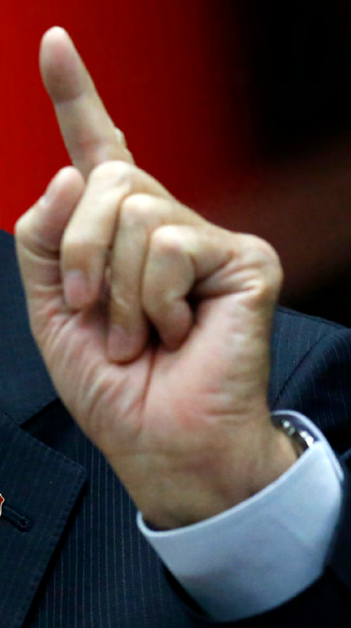

AUTHOR: Insan Yilmaz

\title{
Erdogan's Political Journey: From Victimised Muslim Democrat to Authoritarian, Islamist Populist
}

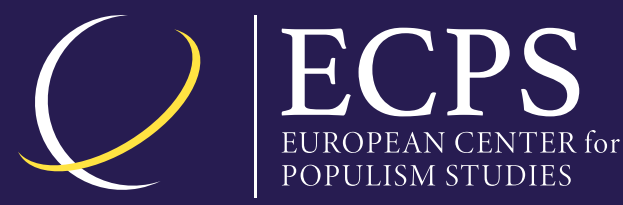




\section{Erdogan's Political}

Journey: From Victimised

Muslim Democrat to

\section{Authoritarian, Islamist Populist}

BY IHSAN YILMAZ

\section{ABSTRACT}

With "the people" on his side, Erdogan has changed the very fabric of Turkish society. Turkey has been changing from an oppressive Kemalist state to an aggressive autocratic and vindictive Islamist state. All opposition is securitised and deemed "the enemy," state institutions spread Erdoganism's populist narratives, and democratic checks and balances have been successfully dismantled.

IHSAN YILMAZ is Research Professor and Chair of Islamic Studies and Intercultural Dialogue at the Alfred Deakin Institute for Citizenship and Globalisation (ADI), Deakin University, Melbourne, Australia.

ECPS Leader Profile Series offer analyses of political leaders and prominent public figures with populist tendencies. Unless otherwise indicated, the views expressed by the author are only attributable him and not to any institution with which they are associated.

The profile available for free downloading from the ECPS website (www. populismstudies.org)

(C)EPS 2021 


\section{Table of contents}

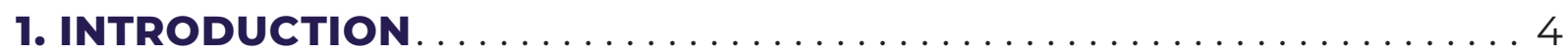

2. THE SHAPE-SHIFTER: ISLAMISM AND YOUNG ERDOGAN $\ldots \ldots \ldots 6$

3. REBELLIOUS ERDOGAN WITH MODERATE VIEWS $\ldots \ldots \ldots \ldots \ldots 9$

4. THE AUTHORITARIAN POPULIST SURFACES $\ldots \ldots \ldots \ldots \ldots \ldots \ldots$

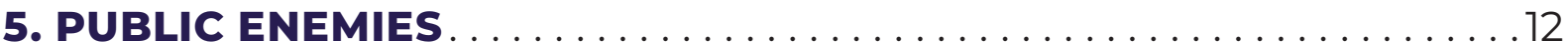

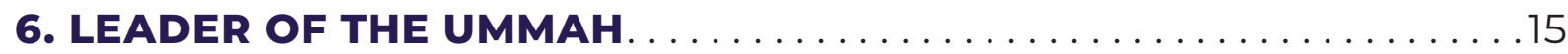

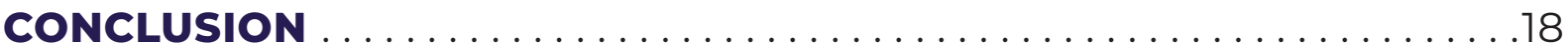

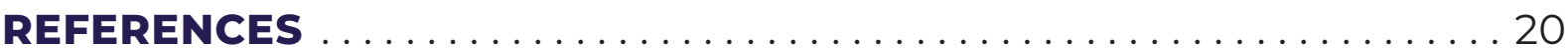




\section{INTRODUCTION}

Recep Tayyip Erdogan is a controversial figure, one who has frequently appeared in international media due to his brusque remarks and increasingly authoritarian practises, both abroad and domestically. During his premiership and subsequent presidency, he successfully changed Turkey's political fabric and is now aiming to influence international politics in unprecedented ways. Erdogan's journey, from mayor of Istanbul to prospective leader of the Muslim world, has been facilitated by exploiting existing power structures or dismantling them, if they don't serve his needs. All the while, he's retained his charisma as an influential Islamist leader working in the best interests of "the people" and the "ummah." By using populist strategies and manipulating democratic institutions, Erdogan is increasingly a populist authoritarian.

Since his National View (Milli Gorus) years in 1970s and 80s under the mentorship of Islamist Necmettin Erbakan, Erdogan's worldview and narrative had always had populist elements that constructed him and practicing Muslim Turks as the real and morally superior owners of Turkey but they had been victims of the Kemalist elite that oppressed them and denied their general will. However, Erdogan's populism has been intensified after he consolidated his power in early 2010s and its anti-Westernist conspiratorial content has increased.

A recent study (Lewis et al. 2019) published in The Guardian shows that Erdogan is the only right-wing leader labelled 'very populist.' Based on the extent to which their speeches have populist ideas, each populist leader under study was given an average populism score. The speeches were graded on a 0-2 scale, ranging from not populist to very populist.According to the study, the average populism score across all 40 countries has doubled from 0.2 in the early 2000s to around 0.4 in 2019. Erdogan was 'somewhat populist' between 2007-2014. However, between the years of 2014-2018, he was 'very populist' with a score of 1.5 out of 2.0. Only Hugo Chavez (1.9) and Nicolas Maduro (1.6) received higher score than Erdogan while Donald Trump and Silvio Berlusconi had a score of only 0.8.

The Republic of Turkey was built in the aftermath of the Ottoman Empire. The events that followed the First World War cost Turkey an empire, a monarchy, caliphate, and the majority of its lands, save for the Anatolian heartland. This has caused immense trauma, anxiety and insecurity among the ruling elite. Mustafa Kemal Ataturk dreamed of reviving a republic from the ashes of empire. Defeated at the hands of the European powers, Ataturk and several followers were convinced that "reinventing" the nation and its "ideal citizens" in the mould of the European civilisation would provide the foundation for a modern, secular republic. For 80 years, Kemalism promoted a nationalist homogenising narrative hinging on the national reconstruction of a Turkey detached from its Ottoman past and rebuilt according to a sec- 
ular blueprint. However, detaching the Turkish people from their Ottoman roots has proved unsuccessful; and Kemalism succeeded only in marginalizing and victimising all ethnic, religious and political minority groups that didn't fit the prototype of the Kemalists' desired citizen, Homo LASTus - Laicist, Ataturkist, Sunni, and Turkish (Yilmaz, 2021).

More than eight decades of repression and denial of the Ottoman past and heterogeneous fabric of society gave room to a resentful counter narrative to rise. While Homo LASTus isolated non-Muslims and non-Turkish groups, it is the conservative Sunni majority who have given birth to an Islamist populist voice. The man voicing their anxieties, discontent, grievances, insecurities, fears and future hopes is Recep Tayyip Erdogan, whose populism has shapeshifted - from centre-right to far-right (Yilmaz, Shipoli and Demir, 2021). His early coalition and representation of resentful liberals, democrats, Muslim and non-Muslim groups, ethnic minorities and civil society organizations that were marginalized and even demonised under Kemalism has gradually transformed to a narrow core of vindictive conservative Sunni, Islamist, ultra-Turkish nationalists.

Through his long political career, Erdogan has always had the benefit of positioning himself as a man of the people due his humble beginnings. This has set him apart from the political and military "elite" (Lowen, 2017; BBC, 2002). The fairy tale-esque nature of his childhood story - the upward mobility of a poor boy raised in a poor and angry urban setting at the margins of Istanbul's more prosperous and Westernised areas becoming the leader of Turkey (Cagaptay, 2017) - inspired his voters. Some even see him as the chosen "sultan" or "caliph" for a "New" Turkey - and possibly even for the Muslim world; others rightly criticize his populist and autocratic tendencies (Lowen, 2017). Yet when closely observed, Erdogan's political ideology is mostly that of the shape-shifter; he ensures his political survival at all costs - even if those costs are damaging the institutional fabric of the country and widening deep rifts in a multi-ethnic and religious society (Genc, 2019).

There have been many studies published on the Erdogan and AKP's recent populism (e.g. Selçuk 2016; Yabancı 2016; Kirdiş and Drhiemur 2016; Özpek and Yaşar 2018; Yilmaz 2018; Castaldo 2018; Özçetin 2019; Sawae 2020; Taş 2020; Yilmaz 2021). As such, this profile will not discuss the Erdogan's populism in detail, leaving it to the other excellent studies to do so. Instead, this will focus on the emotional aspects of Erdogan's populism - including Ottoman nostalgia, anxiety, hate, antagonism, victimhood, and resentment and how they are used to mobilize voters. 


\section{7}

During his teen years, Erdogan encountered politics through Islamist nationalist, anti-Western and anti-Semitic parties. He joined the youth wing of Necmettin Erbakan's National Salvation Party, which was a succession of Erbakan's previous party, the National Order Party that was banned in 1971 for violating the secular values enshrined in the Turkish constitution.

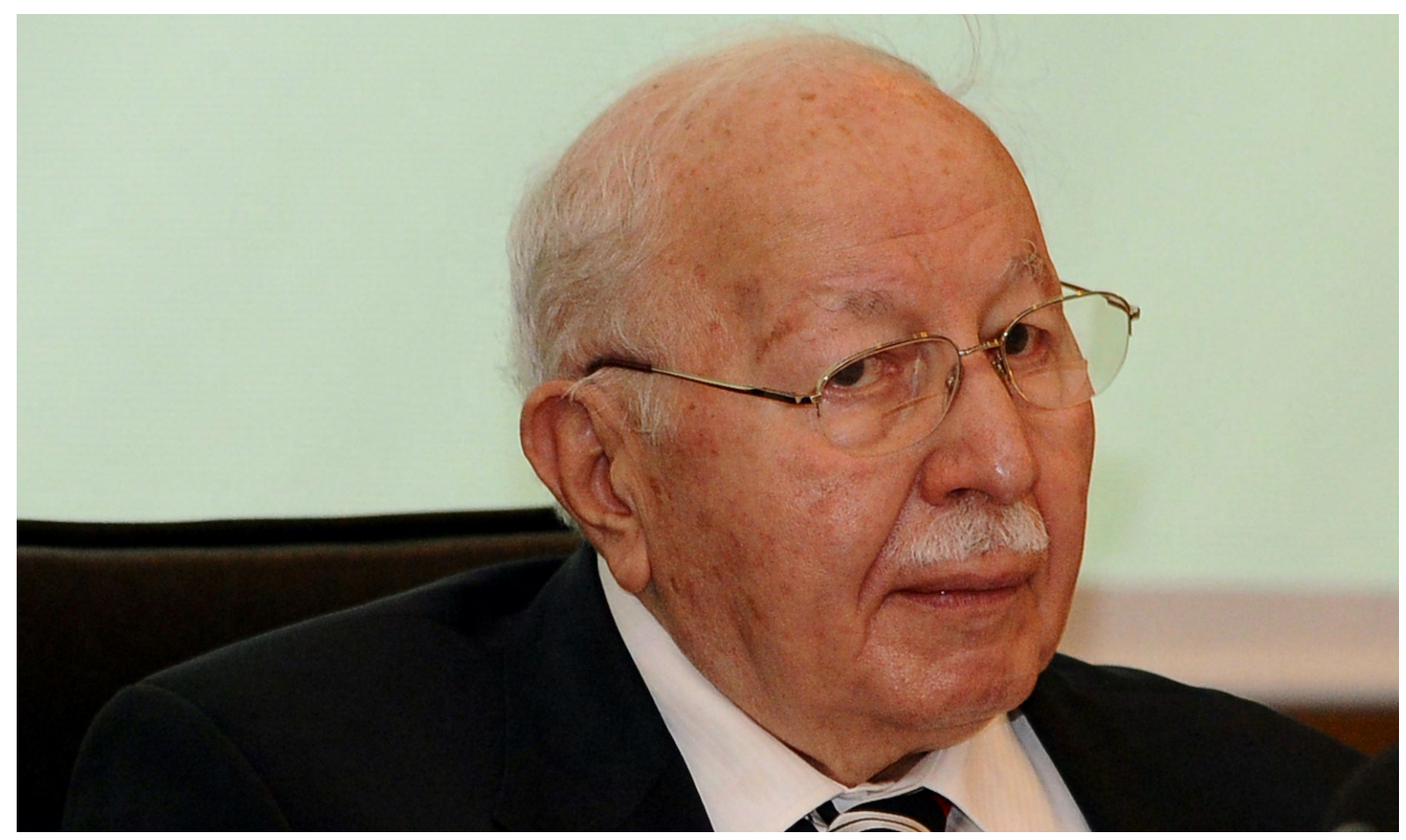

The Shape-Shifter: Islamism and Young Erdogan

To understand his politics and personality, one must start with Erdogan's childhood. Born in the poor Istanbul neighbourhood of Kasimpasa, most of his early life was spent in Rize province, in Turkey's Black Sea region(Lowen,2017). Raised in a working-class family, Erdogan was sent to a religiously-oriented Imam Hatip school by his father, a ferry captain (Genc, 2019). It is unclear if he ever received a university degree from Marmara University due to ambiguity surrounding the issue (BBC, 2016). Nevertheless, his years at the Imam Hatip greatly impacted him. He studied the Quran, the life of the Prophet, and Muslim teachings. He also spent a considerable amount of time improving his Quran recitation, which earned the praise of his friends (Genc, 2019; BBC, 2002).

During his teen years, Erdogan encountered politics through Islamist nationalist, 
anti-Western and anti-Semitic parties. $\mathrm{He}$ joined the youth wing of Necmettin Erbakan's National Salvation Party (Milli Selamet Partisi - MSP), which was a succession of Erbakan's previous party, the National Order Party (Milli Nizam Partisi MNP) that was banned in 1971 for violating the secular values enshrined in the Turkish constitution (Koni, Rosli, \& Zin, 2015). Erbakan was a prominent voice against the secular ideology of Kemalism, which had isolated many Muslim Turks. As an adolescent, Erdogan was exposed to the manifesto of Erbakan's Milli Gorus which based its Islamist ideology around severing the Turkish nation from secularism, Westernism and Capitalism. Milli Gorus was also sympathetic to the Palestinian cause and harshly critical of Zionism. Milli Gorus's ideology was civilizationalist and pan-Islamic and urged the nation to cut its ties with Europe and align with Muslim-majority countries (Sahin \& Dogantekin, 2019).

Erdogan spent considerable time within the MSP's youth group and gained recognition when he organized a boxing match during the visit of the Afghan mujahedeen leader Gulbuddin Hekmatyar. The profound influence of religion on Erdogan's early life was evident when he turned down a spot on an Istanbul city soccer team because the city had a ban on the Islamic beard at that time (Genc, 2019).

After a second ban, Erbakan re-founded his party yet again, this time named the Welfare Party (Refah Partisi - RP). Erdogan's commitment to the party earned him a spot as the party's provincial head in Istanbul. He possessed the art of amassing a huge number of volunteers to hand out flyers and hang posters, displaying his leadership and organizing skills. Most of his time was occupied in political work, and he was soon known for his great oratory skills with emotive mobilizational power. He delivered emotional and resentful speeches decrying "the evil new world order" and supporting "Muslim brothers" across borders that resonated with the victimhood mood of the conservative sections of society (Genc, 2019).

Erdogan's earlier political affiliations helped him not only identify with Isla- mist populism but also see its value in Turkish society. Kemalists had for years suppressed a chain of Sunni Islamist parties as part of their secular agenda, only breeding further resentment. To attach populism with a divinely sanctioned ideology - Islam in this case - was a viable opportunity. Thus, Erdogan did not shy away from using public sentiments and emotions towards religious oppression to gain prominence for himself.

Rising to prominence in 1994, Erdogan was elected mayor of Istanbul. In 1998, the Welfare Party was closed down for violating the tenets of Kemalism. Erdogan became a vocal critic of the government and was arrested for reading a poem that the state claimed, "incited violence." While the arrest was the highlight of his tenure, his agenda was public focused, including improving traffic congestion, dealing with water shortages, and controlling pollution. He remained more pragmatic than Islamist (BBC, 2002).

At the same time, there were hints of religiously motivated actions taken during this period. First, he symbolically limited the use and sale of alcohol (Ozbilgin, 2013). The step was taken under the guise of "public safety," appealing to both religious voters and concerned citizens. He also rebelled by not asking his wife to uncover her head and instead avoided bringing her to official functions and government spaces - covered women were barred from entering public offices and educational institutes as part of the Kemalist ideology to secularize Turkey (BBC, 2002).

His blend of public works and subtle moves to please Islamist groups made him popular. When asked about why he'd developed such a good reputation, Erdogan responded, "I am Istanbul's imam" (Genc, 2019). His statement reflected two major things about his populism. Firstly, as early as the 1990s, his confidence in himself as "the chosen one" was not rooted in democratic measures and values; rather, it was always attached to a "divine" element. The word imam[1] gave him an air of Islamist populism. Secondly, his smirky response shows belief in the idea that Islam and liberal democracies can be merged for the welfare of "the people." Thus, positioning himself as a "Muslim 
Democrat" - one who is able to tolerate non-Muslims and yet at the same time be "Muslim enough" allowed him to amass great public support.

His "imamet" of the city came to an abrupt end when his recitation of a controversial Islamo-nationalist and militarist poem landed him in jail for four months (he was sentenced to ten). The poem featured the lines, "the mosques are our barracks, the domes our helmets, the minarets our bayonets and the faithful our soldiers..." Due to its clear Islamist references, the poem was considered unconstitutional (Genc, 2019). His jail time added to his victimhood and populist popularity; he was viewed as "bold" in the face of the victimising evil Kemalist elite and not afraid of the Kemalist regime that had for decades muffled freedom of expression and religious affiliation. Erdogan established himself as the antithesis to the status quo, another populist hallmark.

For Erdogan, the ultimate aim has always been power, and everything could be instrumentalized to achieve this. He signalled this in the 1990s when, as mayor of Istanbul, he said, "...democracy can't be an objective but an only an instrument... democracy is like a tram. You ride it until you arrive at your destination, then you step off."

Erdogan, following his imprisonment, found himself without a party. Increasingly, the public viewed him as pious and courageous; his humble beginnings added to his credibility as a leader of the "people." Moreover, his reformist attitude and promising improvements during his tenure as mayor of Istanbul earned him a voter base across large sections of society, especially the conservative segments across the rural landscape of Anatolia.

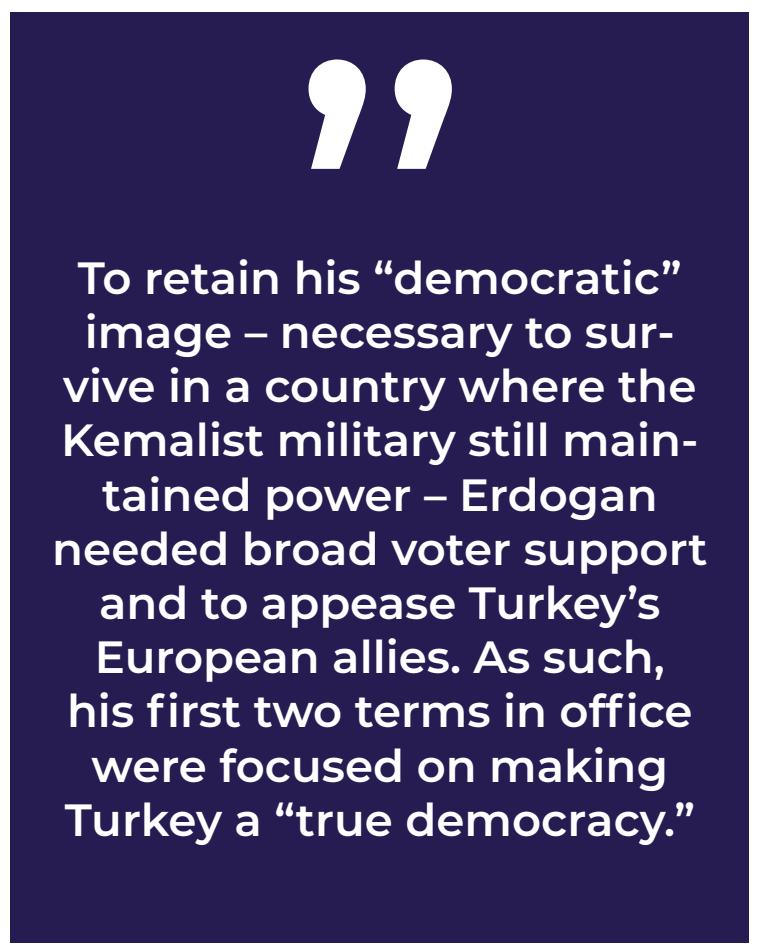




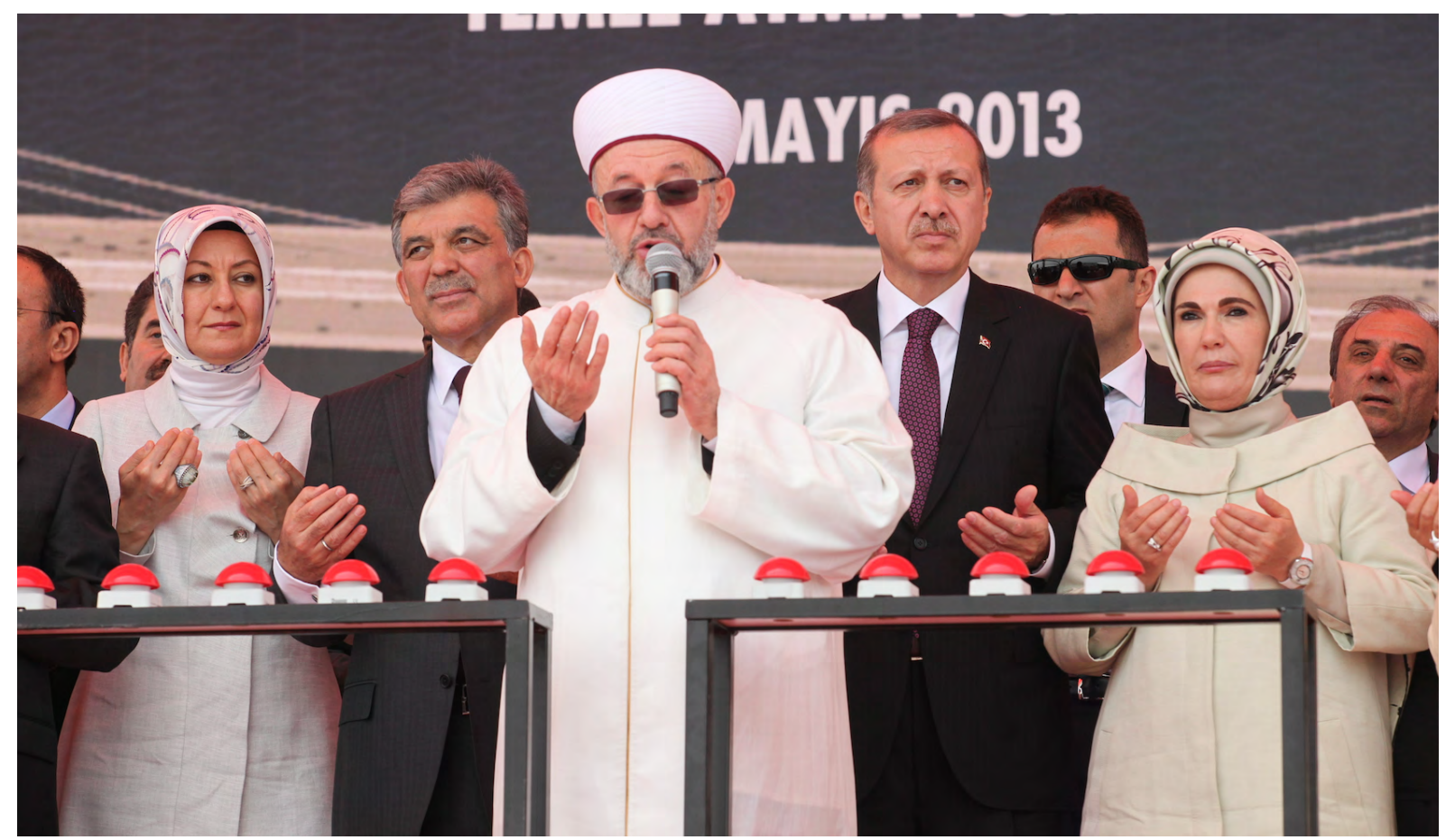

The ceremony of Third Bosphorus bridge was attended by then Turkish President Abdullah Gul and then Prime Minister Recep Tayyip Erdogan on May 29, 2013 in Istanbul. Photo: Sadik Gulec

\section{Rebellious Erdogan with Moderate Views}

While he had been able to connect with the discontent conservative masses, to survive the secular military and judiciary - and also to attract a large voter base of non-Sunnis, non-Muslims, and non-Turks - Erdogan rebranded himself. He moderated his views, especially on the west, to appeal to voters in national elections (Yilmaz, 2009). This was the first example of his pragmatic, populist shape-shifting. He issued statements that were more populous than religious, claiming, "We don't need bearded men who are good Quran reciters; we need people who do their job properly" (Genc, 2019).

The prohibition of Welfare Party in 1998 paved the way for the Virtue Party (Fazilet Partisi - FP), which was also banned in 2001. The dissolution of the Virtue Party led to the birth of two conservative parties. One of them was the Justice and Development Party (AKP), under the leadership of Abdullah Gul and Bulent Arınc. Erdogan was also a major figure in its founding, although he was technically still banned from politics. He described his role in the party, very much the opposite of what it is today, as part of a group of leaders: "a cadre will run the party, and decisions won't be taken under the shadow of one leader..." His role, in his words, was that of an "orchestra chief." He declared, the "age of me-centred politics is over" (Genc, 2019).

The other party to rise from the Virtue Party's ashes was the Felicity Party (Saadet Partisi - SP), which over the years, despite being a right-wing party, has taken an anti-Erdogan stance. During AKP's first election, it was nearly banned, which resulted in Gul running as the party's main candidate, since Erdogan was still technically banned from contesting elections because of his conviction for reciting the poem. Eventually, through a by-election and verdict from the judiciary, Gul stepped down as prime minister in 2003; Erdogan assumed office.

He was ushered in as the beginning of the era of Muslim Democrats (Yilmaz, 2009). It was a model hailed by many as a blueprint for success for the Muslim world. Its proponents claimed it brought "the best of both worlds," combining a hint of 
religion with liberal democratic values.

But the party never truly embraced the image. Instead, this was a survival move for the AKP and Erdogan, who were able to win votes on a broad spectrum of anti-Kemalist sentiments and among those hoping for a truly democratic Turkey. This appeal to the latter groups was the populist side of Erdogan's Islamist politics.

Erdogan's first tenure as prime minister was marked by impressive economic growth for the country and a quest to bridge the gap with Europe. Erdogan boasted, "When we first came to government... our relations with some of the countries in our region were almost non-existent... [now] we have friendly relations with most of our neighbouring countries... we have relations in [the] political, economic, social, cultural, commercial, military areas with many of the countries in the region" (Council on Foreign Relations, 2007). Playing the role of a pro-Western conservative, he insisted on Turkey's presence in NATO and in a bid to secure membership of the European Union (EU) (Söylemez, 2012; Genc, 2011).

To retain his "democratic" image - necessary to survive in a country where the Kemalist military still maintained power - Erdogan needed broad voter support and to appease Turkey's European allies. As such, his first two terms in office were focused on making Turkey a "true democracy." He launched a "democratic war" against the Kemalist elite and the country's system of military tutelage. It is now clear that these were more of a means to an end, as most populists consolidate ideologies to gain support as a way of easing into power.

Erdogan often tried to have it both ways. The Turkish government offered to launch a joint fact-finding mission, with Armenia, into the genocide that took place at the end of World War I; however, the government refused to actually admit the genocide took place. At an intentional forum, Erdogan plainly explained, "Diasporas in some countries lobbying for resolutions in the parliaments of other countries is like an extrajudicial... it's an extrajudicial execution because there is no fact-based process here. So, this is something that Tur- key cannot accept... we told our friends, but we still do not have a response," (Council on Foreign Relations, 2007).

As Erdogan's second national election approached, there were nationwide protests about fears that he and the AKP planned to change Turkey's constitution (de Bendern, 2007; BBC, 2007). Erdogan's populist theatrics garnered public political support and centred around the hope that "new Turkey" would be part of the EU and an economic power.

Populists often use the media and the political bully pulpit to become public fixtures, deepening their connection with the people. It makes them more human and relatable. In the midst of the on-going countrywide protests, Erdogan apparently "fainted" inside his car, which led to a mass panic and a dramatic rescue attempt. The episode added to Erdogan's narrative as a "wronged man" who was being betrayed despite doing all he could for the people and the country (Genc, 2019; Dincsahin 2012).

In 2008, an attempt to close the AKP again failed, although it led to the party's funding being limited. However, Erdogan's relatively moderate first term had resonated with voters: in 2007, he linked his party's win to the ethos of Turkey's democratic and secular values. By electing him, the country had passed the test: "The Turkish Republic is a democratic, secular social state governed by the rule of law, and throughout this process this year, Turkey has gone through an important test of democracy and come out stronger than before from these elections," Erdogan stated (Council on Foreign Relations, 2007).

By the end of his second term, it was clear that Erdogan was gifted at fully utilizing the rifts in Turkish society to gain a popular mandate. He had made "the people" those who were disenfranchised by the Kemalists, positioning himself as a humble outsider - as compared to the Kemalist elite who were the others. He would use his experience to address the country's core issues through democratic means. Economic growth, better diplomatic ties, and a bid to join the EU established him as the "leader" of a peo- 
ple failed by the Kemalist Homo LASTus project.

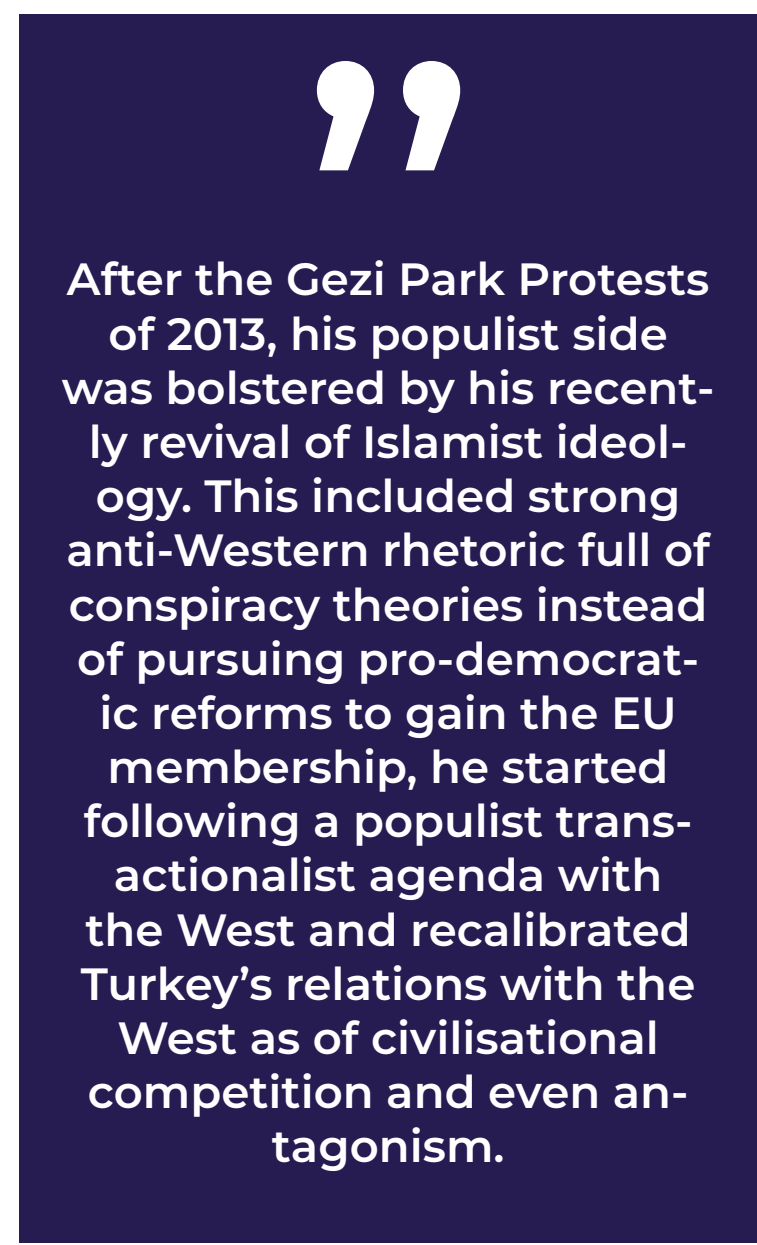

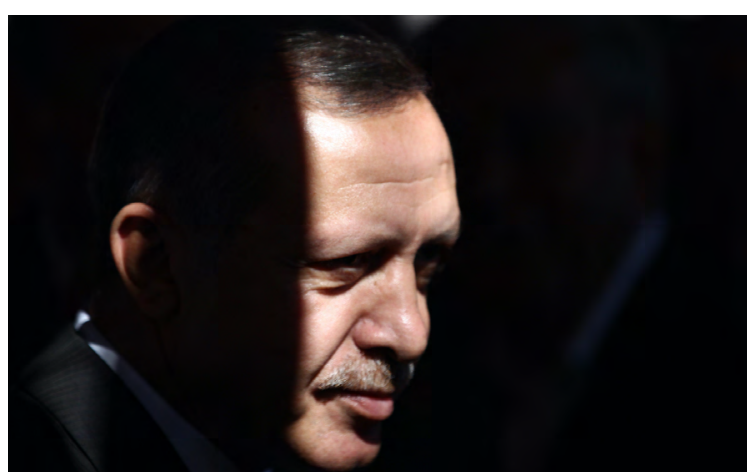

Recep Tayyip Erdoğan. Photo: Kursat Bayhan

\section{The Authoritarian Populist Surfaces}

Erdogan's worldview has always contained populist elements, dating back to his National View (Milli Gorus) years in the 1970s and 80s. In the National View narratives, practicing Muslims were framed as the real owners of the homeland ("the people") but had been victims of the pro-Western and secularist Kemalists (the "evil elite") that oppressed them. However, with the economy slowing down in 2009, Erdogan's populism intensified and soon became the core feature of his narrative (Dinçşahin 2012; Yilmaz and Bashirov 2018). After the Gezi Park Protests of 2013, his populist side was bolstered by his recently revival of Islamist ideology (Onbaşı 2016). This included strong anti-Western rhetoric full of conspiracy theories instead of pursuing pro-democratic reforms to gain the European Union membership, he started following a populist transactionalist agenda with the West and recalibrated Turkey's relations with the West as of civilisational competition and even antagonism (Bashirov and Yilmaz, 2020).

This also has roots in Erbakan's National View Islamism and the totalitarian ideology of Erdogan's more influential role model, Necip Fazil Kisakurek, which included a strong religio-moral component and claimed that "the people" they represented did not only refer to those who were exploited, excluded, oppressed, and victimised but also to practicing Muslims who were constructed as morally superior (Tugal 2002).

He is an Islamist; however, different 
from other Islamists. He developed an Islamist populist style to further appeal to the grievances, resentfulness and hopes of the conservative Turkish Sunni masses that were victimised by the "evil" Kemalist elite who were the pawns of the West. In this narrative, he constructed himself as the only genuine representative of the people and their general will.

\section{Public Enemies}

After spending a considerable amount of time wearing the guise of a Muslim Democrat, Erdogan made a final shapeshift, gradually exposing his populist autocratic style of rule in the aftermath of the 2011 elections (Turkish Weekly, 2011). He used trials such as Sledgehammer (Balyoz) and Ergenekon to increasingly target the military and position himself and the AKP as the voice of democracy against the "corrupt" military. The Kemalist military was public enemy number one. Through populist "otherizing," Erdogan continued to eliminate his greatest opponents and further polarize support in his direction. His actions were justified: they were bringing justice to the Turkish people who had, for generations, been wronged by the elite and corrupt military.

The Ergenekon and Balyoz investigations, which occurred between 2008 2011, gave more legitimacy to Erdogan. High-ranking military generals were put on trial and, as a consequence of the 2010 Constitutional Referendum, a number of Kemalist judiciary members were replaced. This led to a weakening of institutional checks on the AKP from the Kemalist factions. This was one of the first examples of Erdogan undermining democratic institutions by using populist divisiveness to consolidate his position. $\mathrm{He}$ justified it as in the best interest of the people.

Erdogan's commitment to democracy was gradually side-lined for populism, and then Erdogan re-introduced Islamism to the picture. As part of this transformation, the "black Turks" - conservative Muslims who had been oppressed by the Kemal- ist "white Turks" - were position as "the people" and the Kemalists, non-Muslims, non-Sunnis, and non-Turks were the "other" (Yilmaz \& Bashirov, 2018). Erdogan and the AKP used the classic populist card of segregating the "pure" people and the "corrupt" elite. He was the people's man their voice.

Islamism was at the heart of Erdogan's populist agenda. Erdogan lifted the rules of banning women from wearing headscarves in public offices and departments. This was celebrated, as it gave women the autonomy to choose what they wanted. However, it was not done to give women democratic rights, but to consolidate Erdogan's status as a "good Muslim" who stood up for the historically oppressed group. Increasingly, he expressed more conservative views regarding women; for instance, three years later, he publicly claimed, "no Muslim family should consider birth control or family planning... we will multiply our descendants," (BBC, 2020).

Moreover, during his third term, Erdogan imposed hefty taxes and restrictions on alcohol sales (Ozbilgin, 2013). The tax meant that Turkish Airline stopped serving drinks on domestic flights; stores could no longer sell alcoholic beverages between $10 \mathrm{pm}$ to $6 \mathrm{am}$. Lastly, stores selling alcohol had to be at least 100 meters from places of worship or educational institutes. Violators were to face mammoth fines. Brushing away criticism, Erdogan defended his ac-

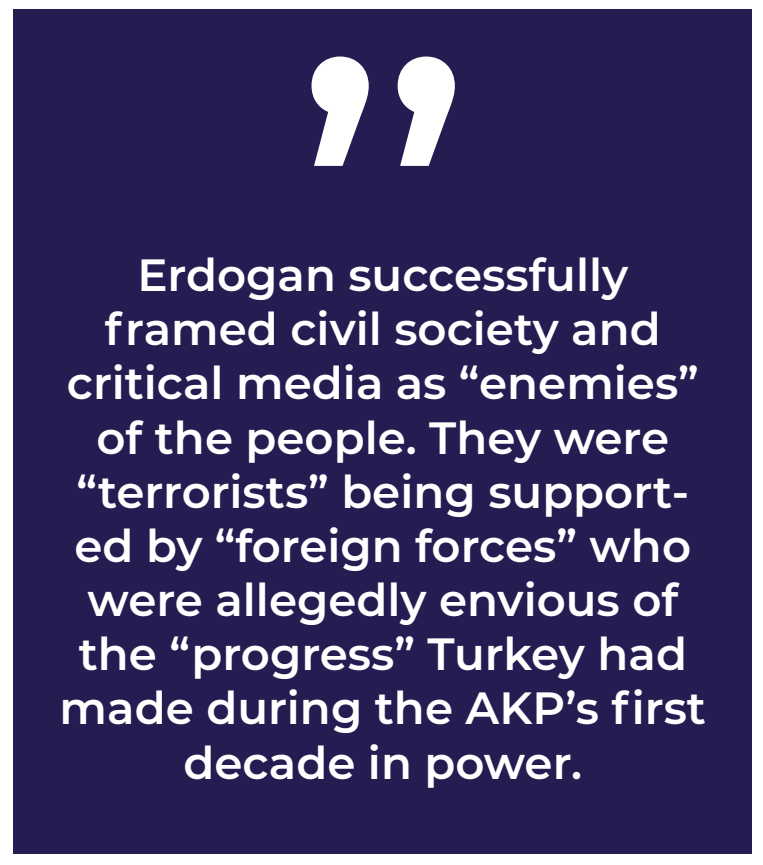


tions: "There are such regulations everywhere in the world. The youth of a nation should be protected from bad habits," (Ozbilgin, 2013). As Erdogan consolidated his power, he used Islamism to change the social fabric, divide society, and legitimize his decisions through "pure" religious motivations.

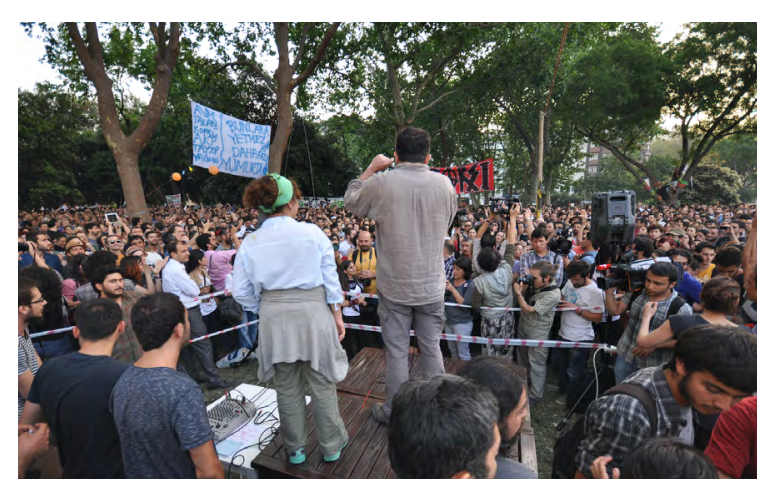

Crowd protesting in Gezi parki, Taksim, istanbul on May 312013.

Erdogan also gradually and successfully turned the media and civil society into "public enemy number one." The Gezi Protests, in 2013, allowed Erdogan to "otherize" anyone who questioned the government's policies. Of people gathered in Gezi, he said: "Are the people only those at Gezi Park? Aren't those who came to meet us at Istanbul airport people, too? Those who are gathered now in Ankara; aren't they people, too?" Erdogan called on the protesters to face off in local elections the next year. "Instead of [occupying] Gezi Park or Kugulu Park [in Ankara], there are seven months [until the elections]. Be patient and let's face off at the ballot box."

The protests allowed Erdogan to play on the existential insecurity of Turkish voters. He played up conspiracies that Western or outside powers were trying to destabilize the country. This again played on the public's collective paranoia, which dated back to the Treaty of Sèvres, when the allied forces divided the defeated Ottoman Empire. This lingering trauma is deeply rooted within many Turkish people.

The Gezi Protests sprang up in the wake of a government plan to build a shopping mall and mosque on the site of Gezi Park, a public area in Istanbul's Taksim Square. At issue was Erdogan's clientelism: he was increasingly running the country by buy- ing the patronage of various individuals. A vast majority of "welfare" projects were centred around privatizing public sectors, and this led to the rise of a new bourgeoisie who profited from the neo-liberal reforms. They were naturally loyal to Erdogan's patronage (Yilmaz \& Bashirov, 2018; Lowen, 2017).

The Gezi Protests erupted after nearly three years of "welfare" being used a guise to hand out contracts to Erdogan-friendly businessmen. The development of the park symbolized the frustrations of marginalized groups: public space was being privatized, to benefit Erdogan and his allies. The peaceful protests were met with state violence; 11 people were killed due to police brutality (Lowen, 2017). Erdogan "otherized" the protestors and their sympathizers, defining their support as "terrorism propaganda" or "insulting" the country's leadership. He also attacked the media supporting the protestors and criticizing the government. In a statement, he said, "There is no difference between a terrorist holding a gun or a bomb and those who use their pen and position to serve their aims" (Lowen, 2017).

Erdogan successfully framed civil society and critical media as "enemies" of the people. They were "terrorists" being supported by "foreign forces" who were allegedly envious of the "progress" Turkey had made during the AKP's first decade in power. All the while, he effectively dismissed any opposition as "propaganda."

In December 2013, a series of police investigations revealed corruption involving high-level AKP elite, including Erdogan's son Bilal and three cabinet ministers. The regime refused to let the investigations proceed: Erdogan characterized them as a "judicial coup" carried out by members of the Gulen Movement and initiated a comprehensive crackdown against the Movement. The police officers in charge of the investigation were arrested. The prosecutors on the case were replaced, and the cases were subsequently closed. In the following months, the regime seized Gulen Movement-affiliated media organisations, appointing trustees and turning them into pro-AKP mouthpieces. They seized other Gulen Movement organisations and businesses, effectively 
usurping thousands of private properties (Day, 2016).

The Gulenists became yet another "enemy." Erdogan alleged members of the Movement were wiretapping himself and other Turkish officials, endangering the state (The Guardian, 2014). Mass arrests of police, civil servants, and members of the judiciary followed. Erdogan accused Gulen of establishing a "parallel structure" within the state. Erdogan pledged that he would "go into their lairs" and bring an end to the parallel structure (Butler, 2014).

Amidst this backdrop, in 2015, Erdogan was elected President. He presented himself as the "man who holds Turkey together" amidst constant threats and crises (Yilmaz, Caman and Bashirov, 2020). Many of these conflicts and crises were of Erdogan's making.

The 2016 coup attempt was to become the magnum opus of Erdogan's populism. He called it a "blessing in disguise." Without evidence, Erdogan blamed the coup on Gulenists. He was targeting Gulen when he said, "I have a message for Pennsylvania (referring to Gulen)... you have engaged in enough treason against this nation. If you dare, come back to your country." Following the coup attempt, any opposition to Erdogan and his party was opposition to Turkey, a country surrounded by "enemies" inside and out (Flinks, 2016).

The purge following the failed coup attempt was merciless. The remaining opposition was crushed. It is estimated that more than 150,000 public servants were deposed from their former jobs, and thousands more were arrested (BBC, 2020).

In the wake of the failed coup, a 2017 referendum abolished the office of Prime Minister, replacing it with an executive presidency. It gave President Erdogan the power to directly appoint top public officials, intervene in the legal system, and impose a state of emergency (BBC, 2020). Erdogan had successfully "otherized" all potential opponents - Kemalist institutions, civil society organizations, and the media. These "others" were a threat to the very survival of Turkey - a thread made crystal clear during the failed coup attempt. Using populism rooted in anti-Western sentiment, pro-Islamist ideology, Turkish nationalism, and conspiracy theories, Erdogan suppressed dissent, broke institutional checks and balances, and established a "new elite" who were a loyal support base in the private sector for himself and his party. He was even able to co-opt the secularist and nationalist opposition parties (Yilmaz, Caman and Bashirov, 2020; Yilmaz, Shipoli and Demir, 2021). Under such circumstance, the referendum was always bound to pass.

As President, Erdogan has become more belligerent, especially towards the West. The man who wanted to build bridges between the West, Middle East, and Turkey has been in constant spats with Western countries. Erdogan has been constantly creating and managing international crises, while at the same time fighting off the "terrorist threat" facing Turkey from Kurdish militias (Tol, 2020).

No credible opposition remains. With Kemalists drawn out of power, religious propaganda in his hand, and the creation of multiple "enemies," he has a comfortable hegemony over Turkish politics. Religion is used to run his "security state" and shore up support. Since disbanding thousands of schools and educational

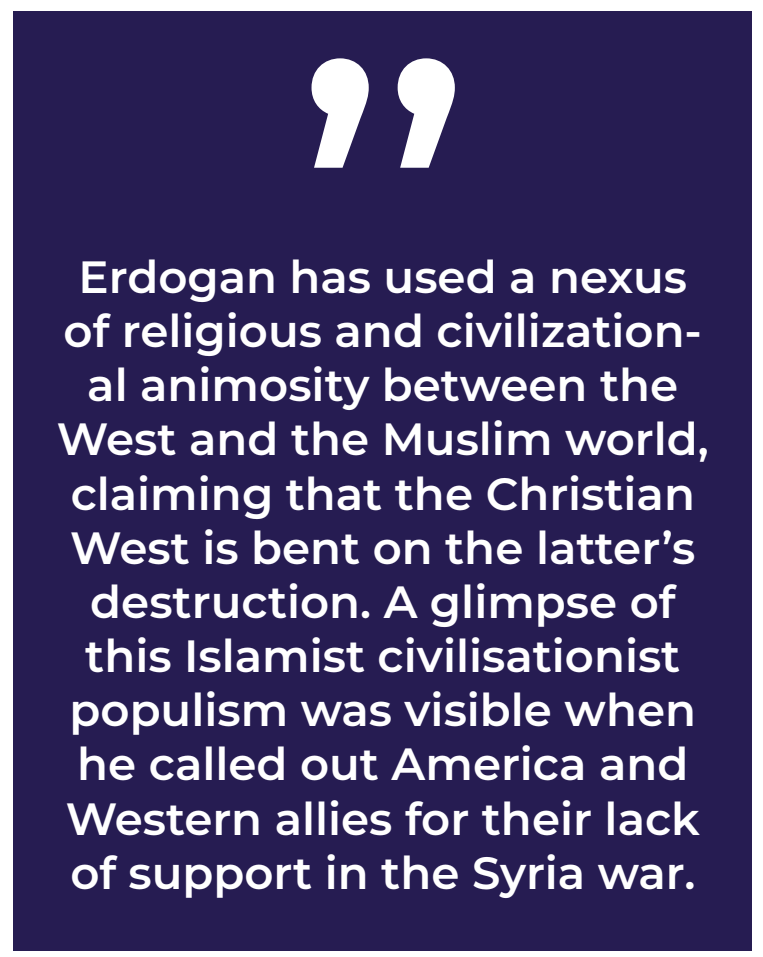


institutes linked to the Gulen Movement, Erdogan has turned them into Islamist schools. The Diyanet (the Directorate of Religious Affairs) is also used as a tool. His handpicked Islamic scholars have issued a fatwa to support the Erdogan regime's actions following the coup.

The views of his most adamant supporters are reflected in a comment by one supporter who expressed his feeling for President Erdogan before the 2017 referendum: "He speaks our language, gets aggressive like we do - and tells the world what we want to say" (Lowen, 2017). He has become the embodiment of "the people": they see themselves reflected in his words and actions.

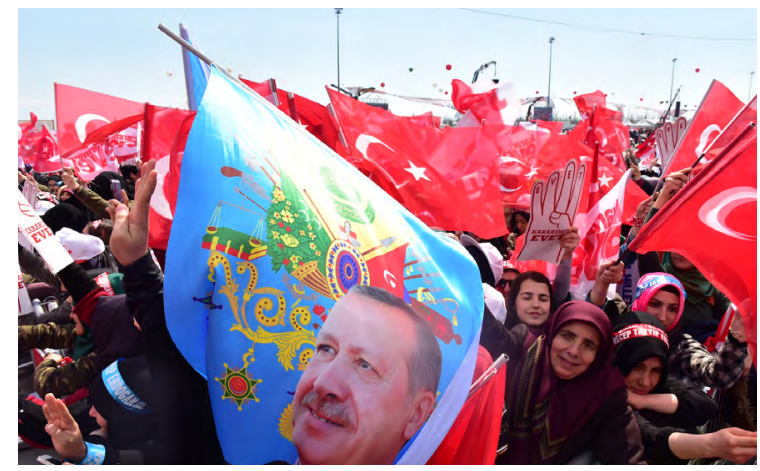

Supporters wait for the arrival of Turkey's President Recep Tayyip Erdogan for a referendum rally in Istanbul on April 8, 2017. Photo: Thomas Koch

\section{Leader of the Ummah}

Modern Turkey still basks in the glorious history of its long Ottoman past. The collapse of the Empire as a result of Treaty of Sèvres led to the formation of the modern-day republic. Erdogan has harnessed the resentment, grievances, trauma, anxieties, fears, insecurity and siege mentality that still exist over the partition of the Empire, occupation of Turkey by the Western powers, the imposition of westernising and secularising Kemalism and its victimisations.

Thus, a wave of Ottoman restorative nostalgia is visible in Erdogan's domestic and foreign policy. Within Turkey, he has used the education system, media, and scheduling of public holidays to shape the common narrative: that Turkish Sunni Muslims should take pride in their Otto- man heritage. Through these gestures, he seeks to restore the country to its former "glory," embedding the idea of "greatness" in Turks. Organizations such as TURGEV and Ensar are collaborations with the Diyanet to facilitate the construction of this narrative (Yabanci, 2019).

Moreover, Erdogan has not only banned critical content from the media. He has successfully replaced it with more "Islamist" or pro-Ottoman oriented content, such as the global hit "Diriliş: Ertugrul," a fictional tale inspired by the alleged founder of the Ottoman Empire. Erdogan's support is visible for such shows when he visits their sets with his family members and "gifts" the show to fellow "brother Muslims" countries for free, in good faith, so that "young minds" can be exposed to a "counter" to Western influence (Banka, 2020).

Erdogan has used religion as a cudgel, to continue dividing society and consolidating his support. His ideology is perhaps best reflected in his speech after Hagia Sophia was controversially reconverted to a mosque, in 2020: "World War I was designed as a fight to grab and share Ottoman lands. In an era when the world order is shaken at the foundations, we will frustrate those who dream the same about the Republic of Turkey ... We tear up those scenarios of those who want to siege our country politically, economically, militarily by realizing a much large vision ... To those who are surprised by Turkey ... rising again like a giant who woke up from its century old sleep, we say: 'it is not over yet!'" (Global Village Space, 2020).

Media and educational institutions are broadcasting Erdoganist ideology overseas. Turkey has given the broadcasting rights of Ottoman-based fiction shows to Azerbaijan and Pakistan. At the same time, the Diyanet has been active in its engagement with the Turkish diaspora as well non-Turkish Muslim minorities living in the West. Erdogan has used a nexus of religious and civilizational animosity between the West and the Muslim world, claiming that the Christian West is bent on the latter's destruction. A glimpse of this Islamist civilisationist populism was visible when he called out America and Western allies for their lack of support in 
the Syria war: "The West sided with terrorists, and all of them attacked us. These include NATO countries, as well as European Union countries. Weren't you against terrorism? Since when you have been acting with them?" (Jones, 2019).

His rhetoric was as strong as ever when he called the French people "sponsors of terrorism" and their head of state "retarded" in the aftermath of a crackdown on radical Muslims following the murder of a schoolteacher by a Muslim youth (Mishra, 2020). He strained relations with Germany after issuing highly insensitive remarks calling out the "fascists" who "will never destroy Turkey's honour" and asking Turks to "defy the grandchildren of Nazis" (Lowen, 2017). Not shying away from championing his "Islamist cause," he has lent his sympathies to the Egypt based pan-Islamic group, the Muslim Brotherhood, and is known to showcase their four-finger salute called the "rabaa" (BBC, 2020).

In addition to lending verbal support to causes such as Palestine and Kashmir, the Turkish military has become involved in conflicts in various Muslim-majority countries such as Libya, Syria, and Azerbaijan. It held joint exercises with Azerbaijan just before its conflict with Armenians in the Nagorno-Karabakh (BBC, 2020). Turkey has sent "peacekeeping troops" to Qatar, Somalia, and Afghanistan, further expanding its role in the Muslim world (Tol, 2020). While Erdogan harbours Sunni Muslim views, he has also urged the Muslim world to unite.

At home and overseas, Islamist Erdogan is the Muslim leader who is the "real" one, representing the authentic values of "the people" or "ummah" - but mainly Sunni Muslims (Çapan \& Zarakol, 2019). Erdogan's version of Islam excludes not only non-Muslims, but also Alevis (Yilmaz and Barry, 2020). The "white Turks" at home are the domestic enemies, while externally, the Western and Zionist "lobbies" are out to cripple the Muslim world (Erdemir \& Lechner, 2018; Yılmaz Z. 2017). Erdogan is the voice of the deprived "real" people, their champion against the interests of the "others."

Ironically, his anti-Western stance and goodwill towards the ummah are cir- cumstantial. Once, Erdogan pledged to seek justice for the Palestinians and has expressed antisemitic views; yet, the softening towards Israel by the Gulf countries has led Erdogan to also take a softer stance: he does not have a problem with the nation itself, but only "the top level." He said, "It is impossible for us to accept Israel's Palestine policies. Their merciless acts there are unacceptable." However, he further elaborated, "If there were no issues at the top level, our ties could have been very different ... We would like to bring our ties to a better point," (Aljazeera, 2020).

While Erdogan has been critical of Western countries, exploiting the religio-cultural divides, he has been busy cultivating closer ties to countries such as Russia and China (despite China oppressing and detaining millions of Uighurs in an obvious attempt of genocide). Russia is an Orthodox Christian majority state, and China is a hybrid-communist state without an official religion (Tol, 2020). Thus, it is evident that religion is a means to an end, an effort to gain influence at home and abroad. It has worked: Erdogan increasingly presents himself abroad as the presumptive heir of the Muslim Ummah.

He expounded on this in a speech he gave at the World Muslim Minorities summit in 2018: "Differences should not be an obstacle to love and brotherhood... Just like the direction of the Qibla - the direction that a Muslim takes when praying is the same, the hearts of all Muslims are also same despite them being in different locations around the world ... Today, attacks on Muslims and refugees have become commonplace in many states that practice democracy and law... Muslim women are being harassed on streets, at workplaces just because they wear headscarves. The Western world wants to defend its own ideology and way of life through anti-Islamism."

While the Kemalists were embarrassed of their heritage, Erdogan has embraced Turkey's Ottoman past. His narratives provide pride and hope to "the people." He has promised them glory through nostalgic references and used a pan-Islamic populism that is transnational in nature to extend Turkey's influence in Muslim countries. Erdogan has placed himself at the 
heart of dreams of the caliphate's revival. $\mathrm{He}$ is the Islamist populist Muslim leader of an increasingly autocratic, populist and necropolitical republic that encourages its citizens to sacrifice their lives for the nation, state, religion and its leader (Yilmaz and Erturk, 2021).

\section{9}

Erdoganism now means a highly autocratic and Islamized populism charged with radical ideas. Erdogan has created the space for his ideology by preying on the populace's "insecurities, anxieties, fears, victimhood, anger, emotions, resentfulness, vindictiveness, siege mentality, anti-Western sentiments, conspiracy theories, militarism, jihadism, glorification of martyrdom, Muslim nationalism and ummatizm."

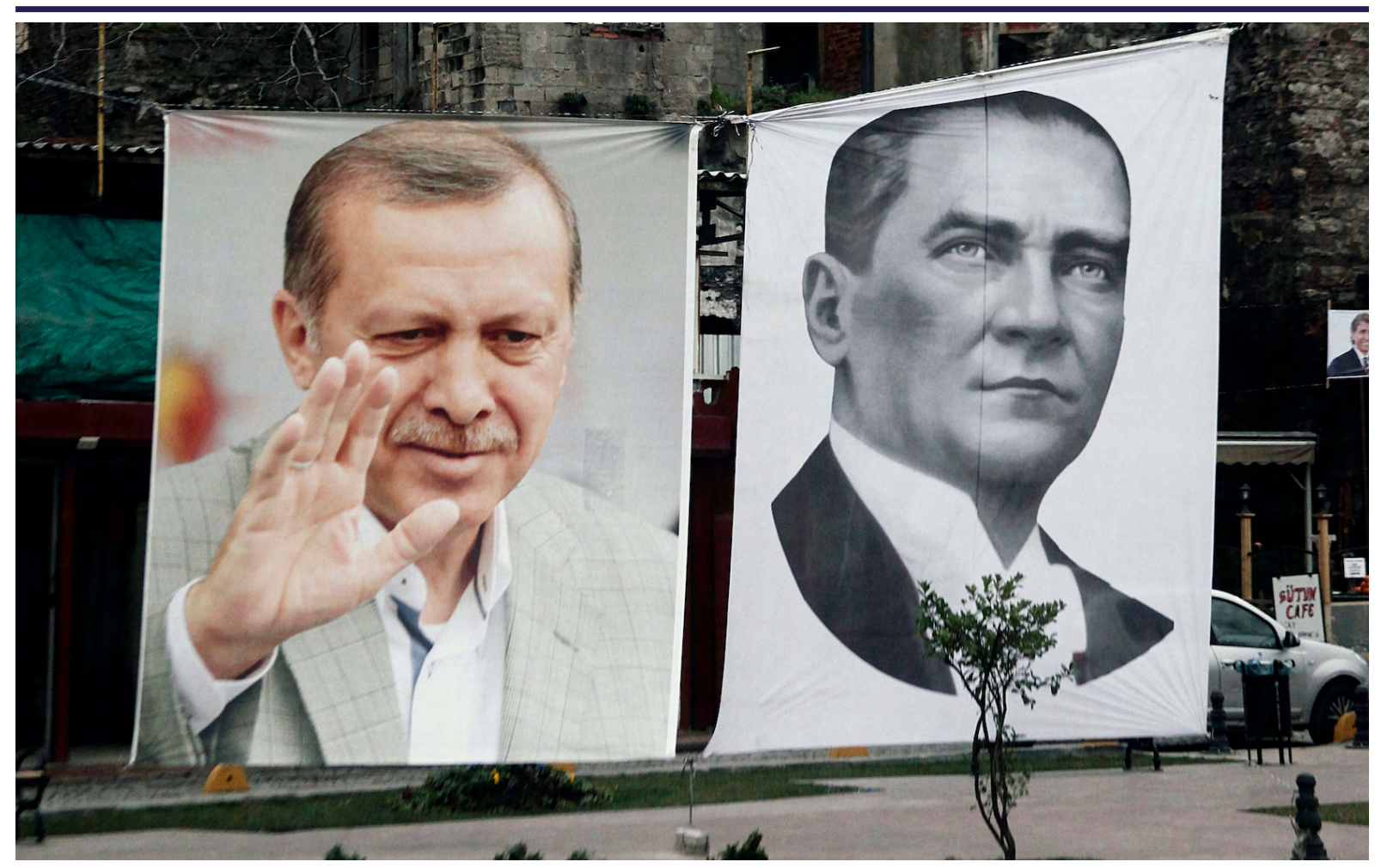

The pictures of Turkish President Recep Tayyip Erdogan and Mustafa Kemal Ataturk are seen at the building in Istanbul on February 14, 2014. Photo: Alexandros Michailidis 


\section{CONCLUSION}

The republic is facing its first reconstruction. While Ataturk was the founding father of the Republic, today Erdogan has become the father of New Turkey. Having reconstructed the republic, he now seeks to influence the broader Muslim world (Genc, 2019).

His populism can be summed up as the "Erdoganist ideology" or "Erdoganism" (Yilmaz and Bashirov, 2018) and has helped him craft a new national identity based on "Islamism, majoritarianism, Muslim nationalism, authoritarianism, patrimonialism, personalism, [the] personality cult of Erdogan, Ottomanist restorative nostalgia, Islamist myth-making, militarism, jihadism, glorification of martyrdom, victimhood, Islamist populism, civilizationism, anti-Westernism, resentfulness, vindictiveness, and anti-Western conspiracy theories to support and legitimize his position in power" (Yilmaz, 2021). In other words, he constructed all the tools to craft an Islamist populist political stage on which to rise.

Beginning his journey in the midst of conservative and Islamist political parties, Erdogan understood that his early survival in politics depended on his ability to pose as a "democrat"; thus, he modelled himself and the AKP as "Muslim Democrat." The only "others" were the corrupt, Western, and elite Kemalists. Thus, the first stage of his political life was supported by a heterogeneous "people" who were Kurds, non-Muslims, and conservatives along with those let-down by eight decades of Kemalist rule. By his third term in office, Kemalist institutions had been diminished, laying the groundwork the emergence of an autocratic leader.

The second transitional phase in Erdogan's political career came when he was faced with increasing homegrown opposition and rejection by the EU. Feeling insufficient, exposed, vulnerable, and attacked, Erdogan was successful in launching a series of attacks on any opposition. These were supported by conspiracy theories. Erdogan made Turkey a "vulnerable state," attacked by conspirators, parallel structures, and devious foreign influence; only he, the strongman, could "save" Turkey restore its glory, dormant for 100 years. To consolidate power, changes in the constitution were introduced in the name of "security"; those defined as the "people" narrowed, driven by ultra-nationalism and Islamism. All the while, Erdogan assumed the position of a strong leader and guide for a great nation that was under attack from all sides.

Erdoganism now means a highly autocratic and Islamized populism charged with radical ideas, such as promises of a "great" Turkey or a "new Turkey." Erdogan, the "leader" or "hope" of the Muslim world is the sole figure at the movement's centre. Erdogan has created the space for his ideology by preying on the populace's "insecurities, anxieties, fears, victimhood, 
anger, emotions, resentfulness, vindictiveness, siege mentality, anti-Western sentiments, conspiracy theories, militarism, jihadism, glorification of martyrdom, Muslim nationalism and ummatizm." Erdogan has become once "the people" - his success is theirs, and vice versa (Yilmaz, 2021).

Erdogan's intervention in the media and educational spheres mean Turkish youth are exposed to his narrative. Thus, not only has he been able to galvanize support from an existing voter bank; he has also been creating a "loyal army" of supporters who believe in the ideals of their leader and identify with an imagined Ottoman Islamist identity that instils in them a "duty" to spread Islam in the public sphere, establish ties with "brother" Muslim and Turkic peoples, and defend the "oppressed" Muslim world against the "anti-Muslim lobby" (namely, the West and Israel) and not hesitate to sacrifice their lives for this cause (Yilmaz, 2021).

With "the people" on his side, Erdogan has changed the very fabric of Turkish society. Turkey has been changing from an oppressive Kemalist state to an aggressive autocratic and vindictive Islamist state. All opposition is securitised and deemed "the enemy," state institutions spread Erdoganism's populist narratives, and democratic checks and balances have been successfully dismantled. All this has been done in the name of "the people." After nearly two decades, Erdogan remains at the centre of it all. 


\section{REFERENCES}

- (2002). "Turkey's charismatic pro-Islamic leader." BBC. Nov. 4, 2002. http://news.bbc. co.uk/2/hi/europe/2270642.stm (accessed on January 5, 2021).

- (2007). "A Conversation with Recep Tayyip Erdogan." Council of Foreign Relations. Sep. 27, 2007. https://www.cfr.org/event/conversation-recep-tayyip-erdogan-O (accessed on January 6,2021$)$.

- (2007). "Secular rally targets Turkish PM." BBC. April. 14, 2007. http://news.bbc.co.uk/2/hi/ europe/6554851.stm (accessed on January 5, 2021).

- (2008). "Turkish ruling party put on trial." BBC. July 1, 2008. http://news.bbc.co.uk/2/hi/europe/7482793.stm (accessed on January 5, 2021).

- (2014). "Turkish police accused of spying on prime minister are arrested." The Guardian. July 22, 2014. https://www.theguardian.com/world/2014/jul/22/turkish-police-accused-spying-prime-minister-arrested (accessed on January 5, 2021).

- (2016). "The curious case of the Turkish President's degree". BBC. June 3, 2016. https:// www.bbc.com/news/blogs-trending-36436200 (accessed on January 5, 2021).

- (2020). "Hagia Sophia: Erdogan presents himself as "reincarnation of Ottoman Empire." The Global Village. July 2, 2020. https://www.globalvillagespace.com/hagia-sophia-erdogan-presents-himself-as-reincarnation-of-ottoman-empire/ (accessed on January 5, 2021).

- (2020). "Recep Tayyip Erdogan: Turkey's pugnacious president." BBC. Oct. 27, 2020. https://www.bbc.com/news/world-europe-13746679 (accessed on January 5, 2021).

- (2020). "Erdogan says Turkey wants better ties with Israel, talks continue." Aljazeera. Dec. 25, 2020. https://www.aljazeera.com/news/2020/12/25/erdogan-says-turkey-wants-betterties-with-israel-talks-continue (accessed on January 6, 2021).

Banka, Neha. (2020). "Explained: This is why Imran Khan is urging Pakistanis to watch 'Diriliş: Ertuğrul'." Indian Express. May 28, 2020. https://indianexpress.com/article/explained/ explained-why-imran-khan-is-urging-pakistanis-to-watch-dirilis-ertugrul-a-turkish-television-drama-6426479/ (accessed on January 5, 2021).

Bashirov, Galib. and I. Yilmaz. (2020). "The Rise of Transactionalism in International Relations: Evidence from Turkey's Relations with the European Union." Australian Journal of International Affairs. DOI: 10.1080/10357718.2019.1693495.

Butler, Daren. (2014). "More Turkish police held as PM Erdogan says purge just beginning." Reuters. https://www.reuters.com/article/instant-article/idINKBNOG50G520140805 (accessed on January 5, 2021).

Çapan, Zeynep Gülşah and Ayşe Zarakol. (2019). “Turkey's ambivalent self: ontological insecurity in 'Kemalism' versus 'Erdoğanism'." Cambridge Review of International Affairs. 32(3), 263-282 (accessed on January 5, 2021).

Day, Michael. (2016). "Bilal Erdogan: Italy names Turkish president's son in money laundering investigation allegedly connected to political corruption." The Independent. Feb. 17, 2016. https://www.independent.co.uk/news/world/europe/bilal-erdogan-italy-investigates-turkish-president-s-son-over-money-laundering-allegedly-connected-corruption-a6879871.html (accessed on January 5, 2021). 
de Bendern, Paul. (2007). "One million Turks rally against government." Reuters. April 29, 2007. https://www.reuters.com/article/worldNews/idUSL2910950920070429 (accessed on January 5, 2021).

Dinçşahin, Şakir. (2012). "A symptomatic analysis of the Justice and Development Party's populism in Turkey, 2007-2010." Government and Opposition. 47(4): 618-640 (accessed on January 5, 2021).

Erdemir, Aykan and Lechner, A. John. (2018). "Erdogan's Anti-Semitism Will Sink Turkey's Economy." Foreign Policy. Dec. 24, 2018. https://foreignpolicy.com/2018/12/24/erdogans-anti-semitism-will-sink-turkeys-economyl (accessed on January 6, 2021).

Filkins, Dexter. (2016). "The Purge Begins in Turkey." The New Yorker. July 16, 2016. https:// www.newyorker.com/news/news-desk/the-purge-begins-in-turkey (accessed on January 5 , 2021).

Freedman, Seth. (2009). "Erdogan's blind faith in Muslims." The Guardian. Nov. 11, 2009. https://www.theguardian.com/commentisfree/2009/nov/11/erdogan-muslims-turkish-sudan-gaza (accessed on January 5, 2021).

Genc, Kaya. (2019). "Erdogan's Way: The Rise and Rule of Turkey's Islamist Shapeshifter." Foreign Affairs. Sep/Oct 2019. https://www.foreignaffairs.com/articles/turkey/2019-08-12/erdogans-way (accessed on January 5, 2021).

Genc, Kaya. (2011). "Turkish crackdown on Kurdish journalists." Index. Dec. 11, 2011. http:// www.indexoncensorship.org/2011/12/turkish-crackdown-on-kurdish-journalists/ (accessed on January 5, 2021).

Hahn, Julia. (2018). "Remembering the Gezi Park protests and the dream of a different Turkey." DW. June 28, 2018. https://www.dw.com/en/remembering-the-gezi-park-protestsand-the-dream-of-a-different-turkey/a-43952443 (accessed on January 5, 2021).

Jones, Dorian. (2019). "Erdogan Criticizes Western Allies Over Syrian Operation Ahead of Putin Meeting." Voice of America. Oct. 21, 2019. https://www.voanews.com/middle-east/erdogan-criticizes-western-allies-over-syrian-operation-ahead-putin-meeting (accessed on January 5, 2021).

Karaveli, H. (2016). "Erdogan's Journey: Conservatism and Authoritarianism in Turkey." Foreign Affairs. 95(6), 121-130. http://www.jstor.org/stable/43948388 (accessed on January 5, 2021).

Koni, Hakan; Rosli, Nurhidayu and Zin, M. A. S. (2015). "History of Islamic Political Movements in Turkey." Asian Social Science. 11(10). DOI: 10.5539/ass.v11n10p339 (accessed on January 6, 2021).

Lewis, P., C. Barr, S. Clarke, A. Voce, C. Levett, and P. Gutiérrez. (2019). "Revealed: The Rise and Rise of Populist Rhetoric". The Guardian, March 6, www.theguardian.com/world/ng-interactive/2019/mar/06/revealed-the-rise-and-rise-of-populist-rhetoric (accessed on February 13,2021$)$.

Lowen, Mark. (2017). "Erdogan's Turkey." BBC. April 13, 2017. https://www.bbc.co.uk/news/resources/idt-sh/Erdogans_Turkey (accessed on January 5, 2021).

Mishra, Pankaj. (2020). "Why French President Macron's clash of civilisations with Islam is misguided." The Print. Oct. 28, 2020. https://theprint.in/opinion/emmanuel-macrons-remarks-on-islam-have-put-frances-global-reputation-at-stake/532423/ (accessed on January 6,2021$)$. 
Ozbilgin, Ozge. (2013). "Turkey bans alcohol advertising and curbs sales." Reuters. May. 24, 2013. https://www.reuters.com/article/us-turkey-alcohol-idUSBRE94NOIA20130524 (accessed on January 5, 2021).

Sahin, Sefa and Dogantekin, Vakkas. (2019). "Molder of new world vision: Turkey's Necmettin Erbakan." Anadolu Agency. Feb. 27, 2019. https://www.aa.com.tr/en/turkey/molder-ofnew-world-vision-turkeys-necmettin-erbakan/1404003 (accessed on January 6, 2021).

Söylemez, Ayça. (2012). "Journalists are in Prison Because of their Writings." Binaet. Jan. 22, 2012. https://bianet.org/english/freedom-of-expression/135635-journalists-are-in-prison-because-of-their-writings (accessed on January 5, 2021).

Tol, Gonul. (2020). "Viewpoint: Why Turkey is flexing its muscles abroad." BBC. Dec. 15, 2020. https://www.bbc.com/news/world-europe-54547304 (accessed on January 5, 2021).

World Muslim Minorities summit, https://www.caribbeanmuslims.com/world-muslim-minorities-summit-held-in-istanbul (accessed on January 5, 2021).

Yabancl, Bilge. (2019). "Work for the Nation, Obey the State, Praise the Ummah: Turkey's Government-oriented Youth Organizations in Cultivating a New Nation." Ethnopolitics. doi: 10.1080/17449057.2019.1676536 (accessed on January 5, 2021).

Yilmaz, Zafer. (2017). "The AKP and the spirit of the 'new' Turkey: imagined victim, reactionary mood, and resentful sovereign." Turkish Studies. 18(3): 482-513, DOI:10.1080/14683849.20 17.1314763 (accessed on January 5, 2021).

Yılmaz, İhsan (2009). "Muslim Democrats in Turkey and Egypt: Participatory Politics as a Catalyst." Insight Turkey, Vol. 11, No. 2, Apr. 2009, pp. 93-112.

Yılmaz, Ihsan (2018). "Islamic Populism and Creating Desirable Citizens in Erdogan's New Turkey." Mediterranean Quarterly. 29 (4), 52-76. doi: https://doi.org/10.1215/10474552-7345451 (accessed on January 9, 2021).

YIlmaz, İhsan. (2021). Creating the Desired Citizen: Ideology, State and Islam in Turkey. Cambridge University Press.

Yılmaz, ỉhsan and Galib, Bashirov. (2018). "AKP after 15 Years: Emergence of Erdoğanism in Turkey." Third World Quarterly. 39(9): 1812-1830 (accessed on January 5, 2021).

YIlmaz, îhsan and James Barry. 2020. The AKP's De-securitization and Re-securitization of a Minority Community: The Alevi Opening, and Closing. Turkish Studies 21(2), 231-253. DOI: $10.1080 / 14683849.2019 .1601564$.

Yılmaz, İhsan, M. E. Caman and G. Bashirov. (2020). "How an Islamist Party Managed to Legitimate Its Authoritarianisation in the Eyes of the Secularist Opposition: The Case of Turkey." Democratization. DOI: 10.1080/13510347.2019.1679772.

Yılmaz, İhsan, E. Shipoli, and M. Demir. (2021). "Authoritarian Resilience through Securitisation: An Islamist Populist Party's Co-optation of A Secularist Far-Right Party." Democratization.

Yılmaz, İhsan and F. Erturk. (2021). Populism, Necropolitics and Authoritarian Stability: The Turkish Case, Third World Quarterly. 


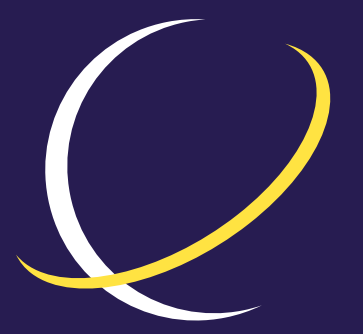

\section{ECPS \\ EUROPEAN CENTER for POPULISM STUDIES}

\section{ABOUT ECPS}

The European Center for Populism Studies (ECPS) is an independent, nonpartisan, nonprofit organization, based in Brussels, for research on and analysis of challenges posed by the resurgence of political populism. ECPS facilitates collaboration among networks of academic experts, practitioners, policymakers, media, and other stakeholders. ECPS offers a platform for the exchange of policy solutions on issues relating to rising populism and provides insights for policy-making and critical analysis to raise broader awareness and engagement through:

\section{Publications}

\section{Academic publications}

Policy reports

White papers

Commentaries

Podcasts and interviews with experts

Events, seminars, workshops, and conferences

\section{Research Programs}

Authoritarianism

Digital Populism

Economics

Environment \& Climate

Extremism \& Radicalisation

\section{Gender}

Human Rights

Foreign Policy

Leadership \& Persona

Migration

\section{ECPS Youth Program}

ECPS Academy 